\title{
E-Commerce in forming Brand Image using Media Publication
}

\author{
$\mathrm{K}_{\mathrm{L}}$ Silaban $^{1 *}, \mathrm{~T}$ Rahajoeningroem ${ }^{2}$ \\ \{krislitasilaban@gmail.com ${ }^{1}$, tri.rahajoeningroem@email.unikom.ac.id ${ }^{2}$ \} \\ Department of Communication Science, Universitas Komputer, Indonesia ${ }^{1}$ \\ Department of Electrical Engineering, Universitas Komputer Indonesia ${ }^{2}$
}

\begin{abstract}
The purpose of this study is to identify e-commerce in shaping brand image through publication media. The method used in this research is a descriptive method to present a complete picture of the situation related to several situations of the variables under study. The result of this study is to identify the extent to which e-commerce shapes the brand image. This research was conducted by discussing e-commerce activities in publication media to shape brand image. So it is expected that the impact of this research will result in e-commerce not only selling products but also providing information and promotion with the strength of the product.
\end{abstract}

Keywords: E-commerce, brand, media, publication

\section{Introduction}

The rapid adoption of the Web as a commercial medium has caused firms to experiment with innovative ways of doing business. Those firms that effectively market themselves on the Web have a distinct advantage to maximize shopping preferences, online retail businesses see trends online, and then implement the e-commerce system as in tune with market demands [1]. To overcome the product overload of online shoppers, a variety of recommendation methods have been developed [2]. Recommender systems are being utilized by an ever-increasing number of E-commerce sites to help consumers discover products to buy. According to research, Weblogs are massive, heterogeneous, and contain huge potential value [3]. To effectively mine these resources as well as provide more efficient services for users, intelligent e-commerce model was set up, and laws, patterns, and knowledge were acquired by Web usage mining to support e-commerce intelligence [4].

The most important constructs for increasing initial trust in our experimental context are branding and Web site quality [5]. The research found that some positive brand associations increase significantly after the visit and that attitude towards the website has an impact on attitude towards the brand [6]. Compared with other studies, the impact of website content including information and design dimensions on e-marketing effectiveness along with e-trust as mediator variables [7]. Several factors in building brand online are important content, functions, and design elements of brand sites throughout six dimensions: text information, multimedia information, interface design, loyalist support, promotional synergy, and interactivity.[8] The concept "brand image" has drawn significant attention from academics and practitioners since it was put forward, because it played an important role in marketing activities. Although brand image was recognized as the driving force of brand asset and brand performance, few studies 
have elaborated on the relationship between brand image and brand equity. Moreover, web design features are important for online relationship marketing [9]. Both commitment dimensions were found to be precursors of trust whereas affective commitment is the precursor of e-loyalty [10]. The findings show that empathy and trust are the most direct factors influencing online purchase intentions. To increase consumer buying interest online, service providers must provide services with empathy and increase customer trust [11]. Media publications, especially for e-commerce, have to focus on what customers needed and feel, so empathy and trust are built.

The purpose of this research is to identify e-commerce in forming a brand image using publication media so the product of a brand will produce a good brand image and will also lead to customer trust. Moreover, this writing method used descriptive research method, which presents a complete picture of the situation related to several situations of the variables studied.

\section{Method}

This research used a descriptive method to find out the variables related to e-commerce, Brand Image, and publication media website and used previous research related to e-commerce, brand image, and media publication websites. So that it can analyze how much the influence of e-commerce in forming brand image through publication media. In this research, e-commerce named Nature Republic is used as an object. Nature Republic is cosmetic brand from South Korea created in 2009. The aspect that analyzes is web display, brand image, product details, and media.

\section{Results and Discussion}

E-commerce is very important in forming a brand image. According to Kotler, a brand image is several beliefs about the brand. Brand image determines the position of the product because it is directly related to the consumer's perception of the product. Publication media is one of e-commerce's way of creating brand image for consumers. As by marketing products through publication media such as media websites can build brand image to consumers [12]. Ecommerce in the publication media provides information, promotes and sells its products.

In E-commerce websites, there is a tag line. The tag line can also form brand image for consumers. Showing the strength of the product will determine a strong position for competing products in the business market. Nature Republic uses natural materials as their strength and stated in the tag line. In the main view, there is a display that shows menus and sub-menus as well as some optional information. The menu display here is made to show how Nature Republic brand attracts the attention of its consumers by providing an attractive appearance (Figure 1). 


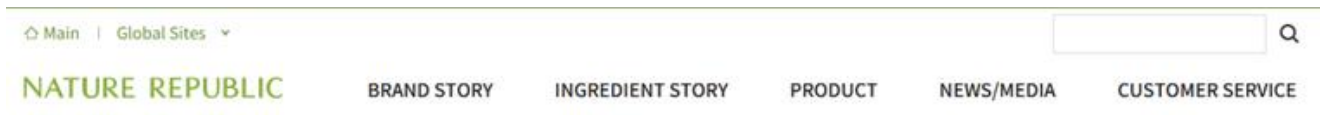

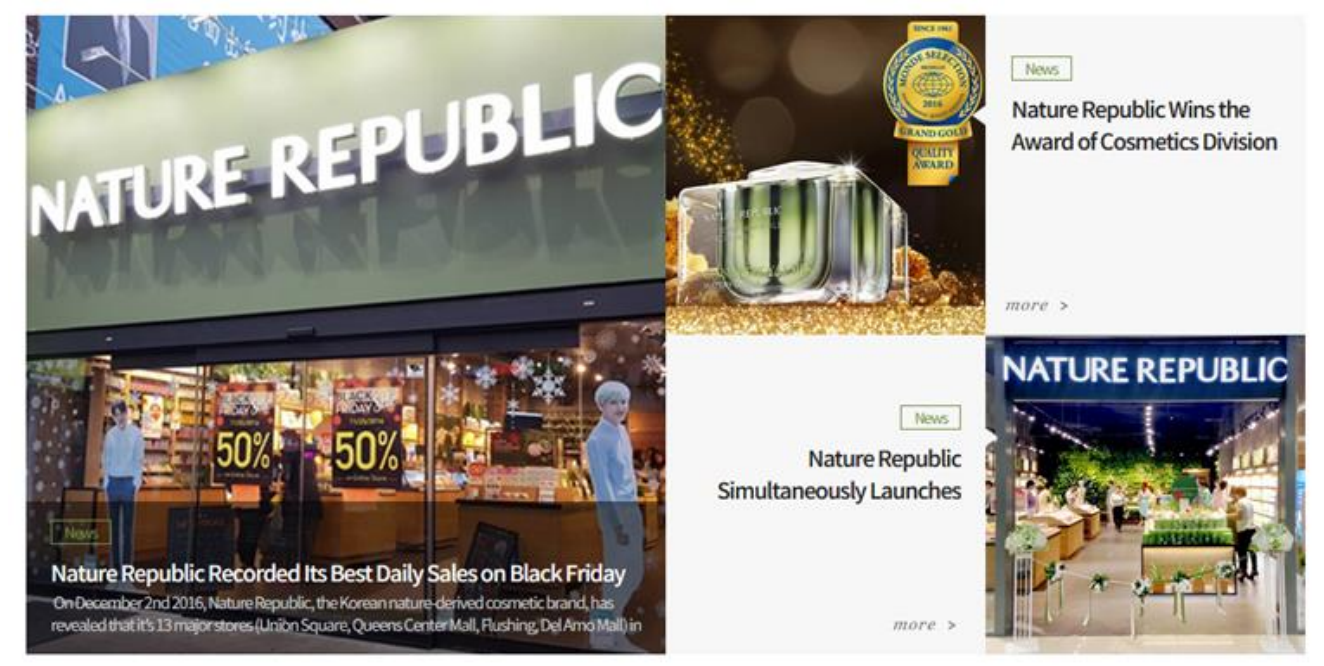

Fig 1. Main menu. Figure was adapted from naturerepublic.id on June 23rd,2018.

The Brand Story here is how e-commerce explains product identity and how products can be formed so that consumers could know the product. Nature Republic brand shows that the product comes from nature. Material stories contain materials for making the product. It is shown that the ingredients possessed have very supportive properties in making the brand. (Figure 2) 


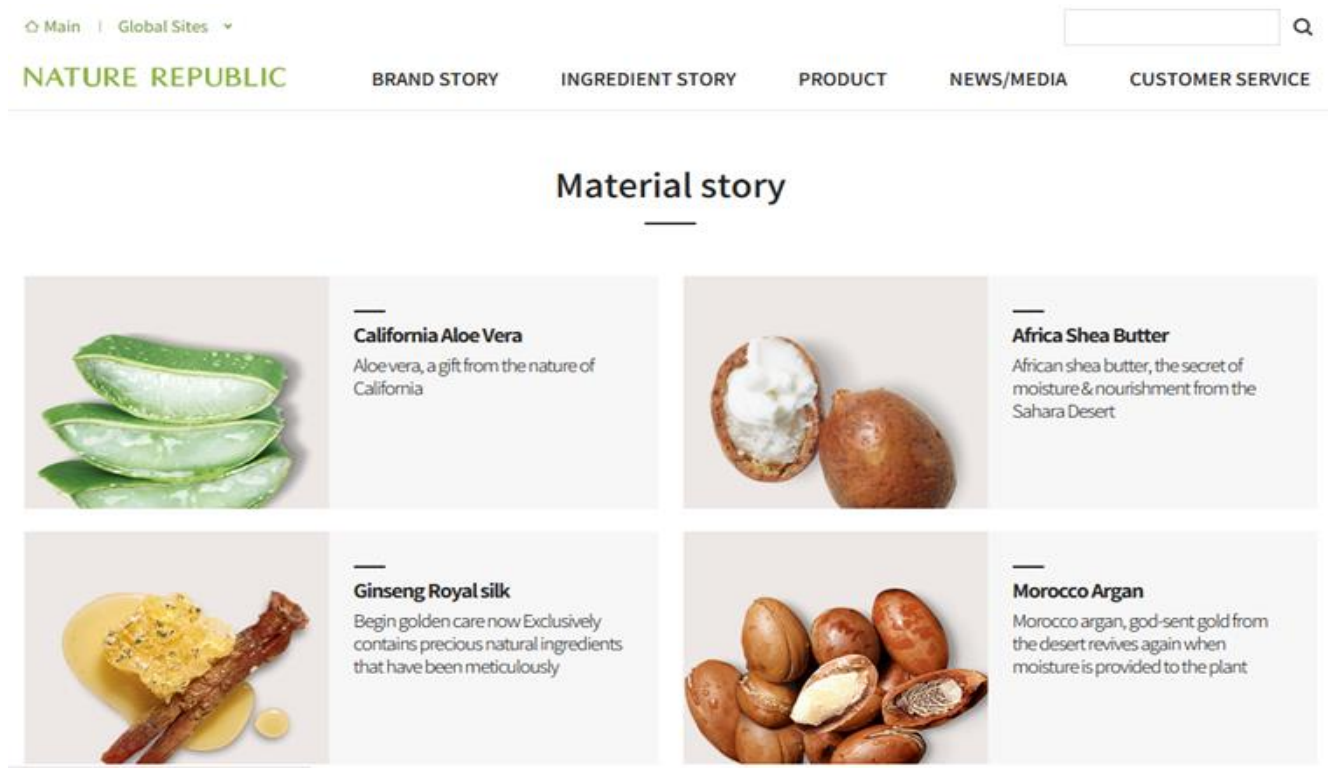

Fig 2. Material Story. Figure was adapted from naturerepublic.id on June 23rd,2018.

Nature Republic owned several variants for the products, each product contains the benefits of various types, such as poverty, cleaning, pack \& mack, makeup base, point makeup. It shows that they are present to focus on one type of part, namely cosmetics and present to provide solutions for consumers. (Figure 3). As mentioned before, branding and design are important in e-commerce [8], but focus on customers' needed is also as important as design. A dividing section in different categories makes users easier to meet their needs.

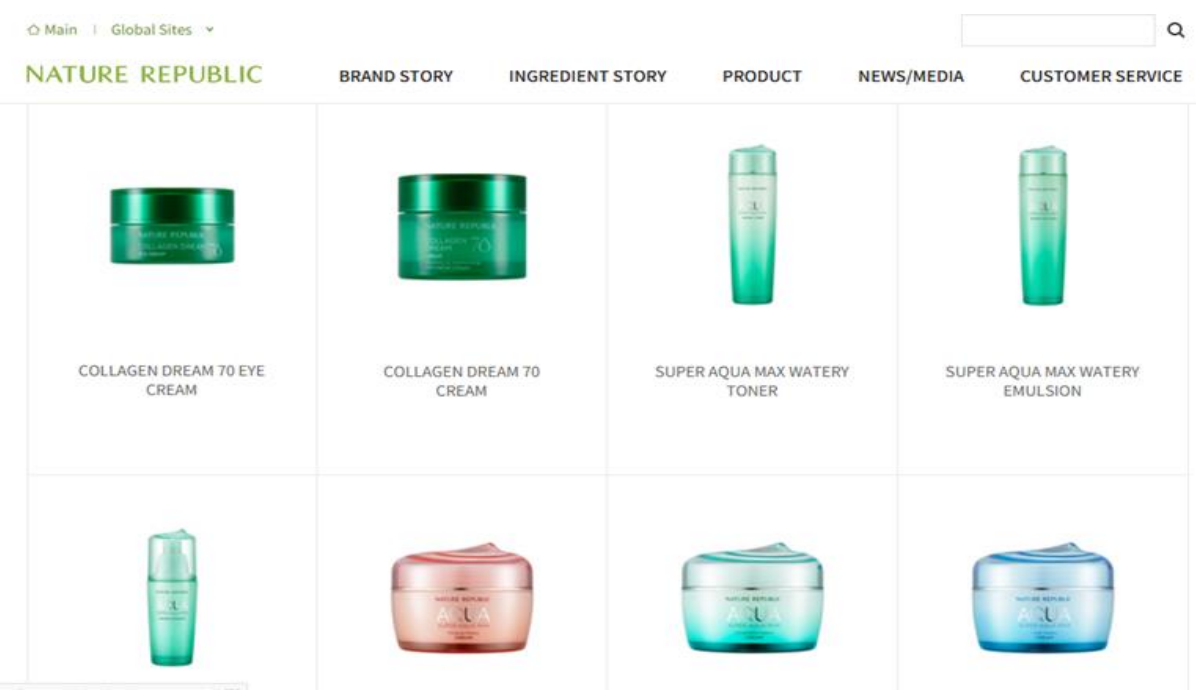

Fig 3. Product Menu. Figure was adapted from naturerepublic.id on June 23rd,2018. 
E-commerce also shows consumers about their product that being the mainstay and has a high level of sales. It will also make the consumer has a picture for new consumers to choose their products (Figure 4)
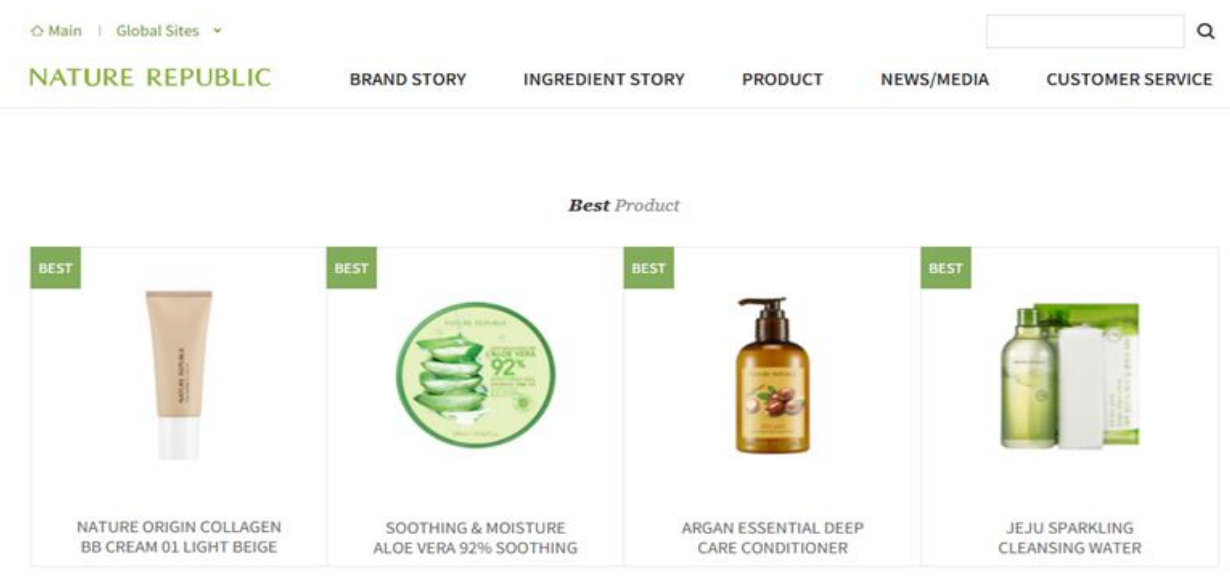

Fig 4. Best Product. Figure was adapted from naturerepublic.id on June 23rd,2018.

News / Media is a means for e-commerce to provide information towards consumers about matters related to the product. This is a means for e-commerce to establish good relationships with consumers (Figure 5).

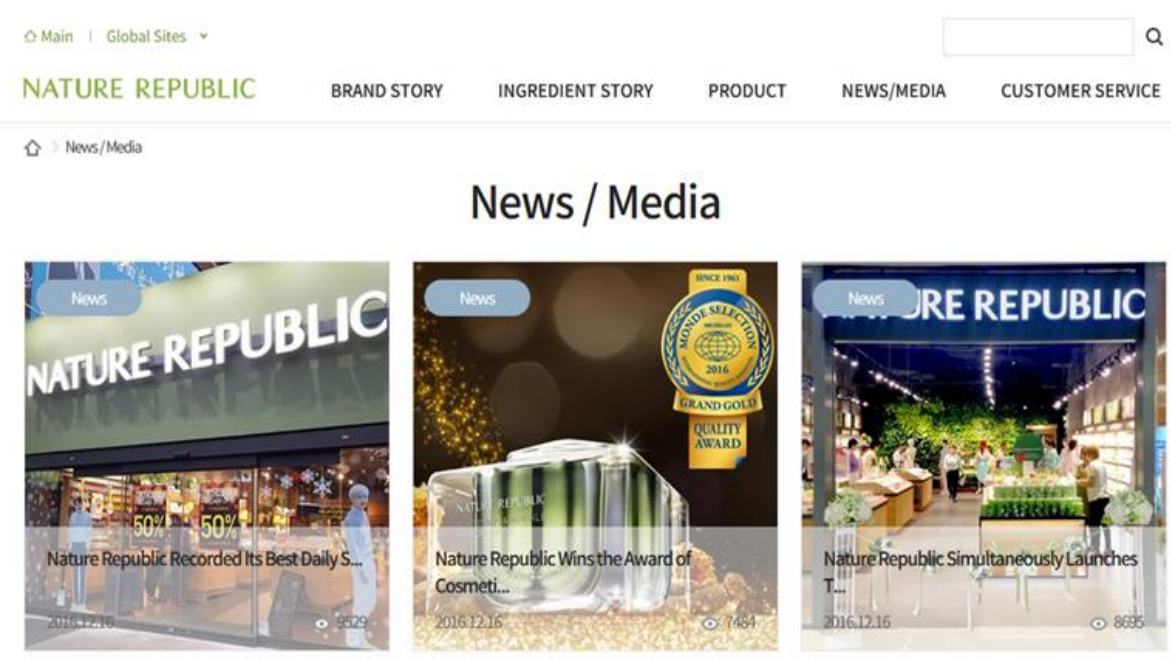

Fig 5. News/Medi. Figure was adobted from naturerepublic.id on June 25th,2018. 


\section{Conclusion}

One of the reasons why the user uses a product is also based on the presence of e-commerce. To give a good impression, a product requires e-commerce to always carry out its activities in the world of publications so that it will have an impact on its brand impression. In using ecommerce, publication media not only focusing on selling products but also in providing information and promotion with the strength of the product.

\section{References}

[1] Wen, H. J., Chen, H. G., \& Hwang, H. G.: E-commerce Web site design: strategies and models. Information management \& computer security, 9(1), 5-12. (2001).

[2] Soegoto, E. S.: Entrepreneurship Menjadi Pebisnis Ulung Edisi Revisi. Elex Media Komputindo. (2014).

[3] Daoud, M., Naqvi, S. K., \& Ahmad, A.: Opinion Observer: Recommendation System on ECommerce Website. International Journal of Computer Applications, 105. (2014).

[4] YU, X. B., GUO, S. S., \& HUANG, X. R.: Intelligent e-commerce based on Web usage mining and its application. Computer Integrated Manufacturing Systems, 2, 53-58. (2010).

[5] Lowry, P. B., Vance, A., Moody, G., Beckman, B., \& Read, A.: Explaining and predicting the impact of branding alliances and web site quality on initial consumer trust of e-commerce web sites. Journal of Management Information Systems, 24(4), 199-224. (2008).

[6] Müller, B., \& Chandon, J. L.: The impact of a World Wide Web site visit on brand image in the motor vehicle and mobile telephone industries. Journal of Marketing Communications, 10(2), 153-165. (2004).

[7] Rahimnia, F., \& Hassanzadeh, J. F.: The impact of website content dimension and e-trust on emarketing effectiveness: The case of Iranian commercial saffron corporations. Information \& Management, 50(5), 240-247. (2013).

[8] Dou, W., \& Krishnamurthy, S.: Using brand websites to build brands online: A product versus service brand comparison. Journal of Advertising Research, 47(2), 193-206. (2007).

[9] Zhang, Y.: The impact of brand image on consumer behavior: a literature review. Open journal of business and management, 3(1). (2015).

[10] Bilgihan, A., \& Bujisic, M.: The effect of website features in online relationship marketing: A case of online hotel booking. Electronic Commerce Research and Applications, 14(4), 222-232. (2015).

[11] Sam, M., Fazli, M., \& Tahir, M. N. H.: Website quality and consumer online purchase intention of air ticket. (2009).

[12] Delone, W. H., \& Mclean, E. R.: Measuring e-commerce success: Applying the DeLone \& McLean information systems success model. International Journal of electronic commerce, 9(1), 3147. (2004). 